\title{
Commentary: Elon Musk (Space X) Has Gone Nuts
}

\author{
Bruce Gagnon
}

Global Network Against Weapons \& Nuclear Power in Space
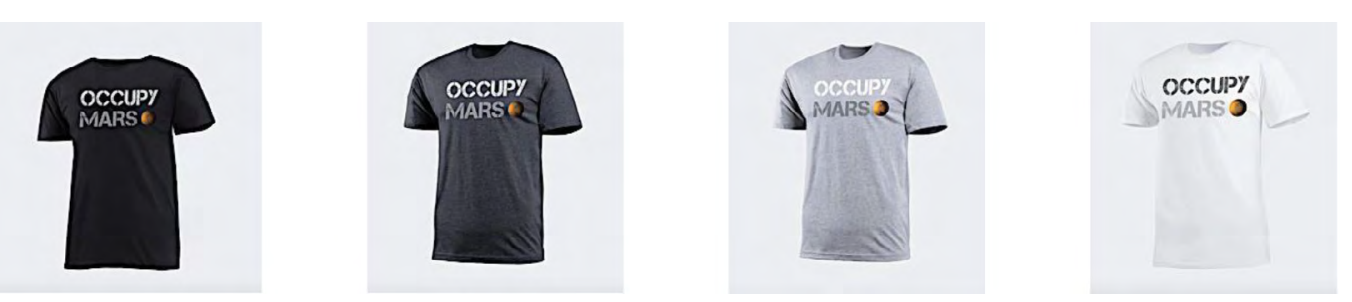

Images courtesy of SpaceX product website

\section{Abstract}

Elon Musk, and his company SpaceX, has a plan to take control of Mars. They want to "terraform" the dusty red planet to make it green and livable like our Mother Earth.

The topography of Mars is described as:

"A hypothetical program that will consist of a planetary engineering project or a concurrent project, with the purpose of transforming the planet from hostile life to life on earth so that it can sustainably accommodate humans and other unprotected or mediated life forms. Presumably, the process will involve restoring the existing climate, atmosphere and surface of the earth through various resource-intensive programs and the installation of one or more new ecosystems." (Wikipedia, 2021).

It is estimated that more than 10,000 nuclear bombs will be required to implement Musk's plan. A nuclear bomb will also make Mars radioactive. The nuclear bomb that Musk wants to build will be transported to Mars by the 1,000-spacecraft fleet Musk wants to build, similar to the nuclear bomb that exploded on December 9, 2020. Such radioactivity will undoubtedly incur long-term damage to Earth.

Keywords: Elon Musk, SpaceX, Mars, terrain, nuclear weapons, cost, morality, law, earth. 


\section{Comentario: Elon Musk (Space X) se ha vuelto loco}

\section{RESUMEN}

Elon Musk y su empresa SpaceX tienen un plan para tomar el control de Marte. Quieren "terraformar” el polvoriento planeta rojo para hacerlo verde y habitable como nuestra Madre Tierra. La terraformación de Marte se describe como

"Un procedimiento hipotético que consistiría en un proyecto de ingeniería planetaria o proyectos concurrentes, con el objetivo de transformar el planeta de una vida hostil a terrestre a una que pueda albergar de manera sostenible a humanos y otras formas de vida libres de protección o mediación. El proceso presumiblemente implicaría la rehabilitación del clima, la atmósfera y la superficie existentes del planeta a través de una variedad de iniciativas intensivas en recursos y la instalación de un sistema o sistemas ecológicos novedosos"(Wikipedia, 2021).

Se ha proyectado que se necesitarían más de 10.000 bombas nucleares para llevar a cabo el plan de Musk. Las explosiones de bombas nucleares también convertirían a Marte en radiactivo. Las bombas nucleares serían llevadas a Marte en la flota de 1,000 naves estelares que Musk quiere construir, similar a la que explotó el 9 de diciembre de 2020. En este comentario, analizo cuestiones importantes que deben considerarse en torno al costo, la ética, y las implicaciones legales que una devastación tan prolongada infligiría aquí en la Tierra.

Palabras clave: Elon Musk, Space-X, Mars, terraform, bombas nucleares, costo, ética, legal, Tierra

\section{评论：Elon Musk（Space X）疯了}

\section{摘要}

伊隆 -马斯克 (Elon Musk) 和他的公司SpaceX计划控制火 星。他们想 “地形化” 尘土飞扬的红色星球，使其像我们的 地球母亲一样绿色宜居。火星的地形描述为

“一种假设的程序，该程序将由一个行星工程项目或一个并 发项目组成, 目的是将地球从敌对生命转变为地球生命, 使 其能够可持续地容纳人类和其他不受保护或调解的生命形 
式。据推测, 该过程将涉及通过各种资源密集型计划和安装

一个或多个新型生态系统来恢复地球上现有的气候, 大气和 地表”（维基百科, 2021年）。

预计实施马斯克的计划将需要10,000多枚核弹。核弹爆炸也 会使火星具有放射性。马斯克想制造的核弹将由马斯克想要 建造的 1000 艘飞船舰队运送到火星，类似于2020年12月9日爆 炸的核弹。这样长时间的破坏将在地球上造成。

关键词: 伊隆-马斯克 (Elon Musk), Space-X, 火星, 地 形, 核武器, 成本, 道德, 法律, 地球。

$\mathrm{E}$ lon Musk, and his company SpaceX, has a plan to take control of Mars. They want to "terraform" the dusty red planet to make it green and livable like our Mother Earth.

The first time I can recall hearing about Terraforming Mars was years ago while on a speaking tour in Southern California. I picked up a copy of the LA Times and read an article about the Mars Society, which has dreams of moving our human civilization to this faraway planet. The article quoted Mars Society President Robert Zubrin (a Lockheed Martin executive) who called the Earth "a rotting, dying, stinking planet," and made the case for the transformation of Mars.

Imagine the cost. Why not instead spend money to heal our lush, beautiful, colorful home? What about the ethical considerations of humans deciding that another planet ought to be transformed for our "use?" What about the legal implications, as the United Nation's Outer Space Treaty forbids such egotistical domination plans?
I am immediately reminded of the Star Trek episode "Prime Directive." The Prime Directive, also known as Starfleet General Order 1, the Non-Interference Directive, was the embodiment of one of Starfleet's most important ethical principles: noninterference with other cultures and civilizations.

In other words, "Do no harm."

But Elon Musk wants to do big harm to Mars and whatever elemental life that might exist there.

In an article posted on CounterPunch, journalism professor Karl Grossman writes that Elon Musk, founder and CEO of SpaceX, has been touting the detonation of nuclear bombs on Mars, he says, "to transform it into an Earth-like planet."

As Business Insider further explains, Musk "has championed the idea of launching nuclear weapons just over Mars' poles since 2015. He believes it will help warm the planet and make it more hospitable for human life."

As space.com says: "The explosions would vaporize a fair chunk of 
Mars' ice caps, liberating enough water vapor and carbon dioxide-both potent greenhouse gases-to warm up the planet substantially, the idea goes."

It's been projected that it would take more than 10,000 nuclear bombs to carry out Musk's plan. The nuclear bomb explosions would also render Mars radioactive. The nuclear bombs would be carried to Mars on the fleet of 1,000 Starships that Musk wants to build-similar to the one that blew up on December 9, 2020 (Figure 1).

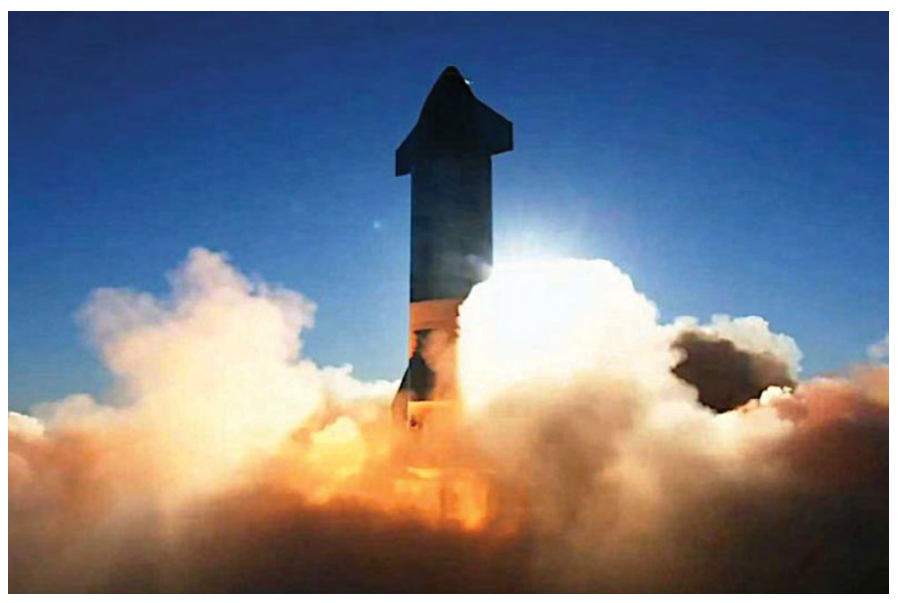

Figure 1. SpaceX's Starship SNB prototype prior to exploding. Image courtesy of SpaceX AFP via Getty Images

SpaceX also sells T-shirts emblazoned with the words "Nuke Mars."

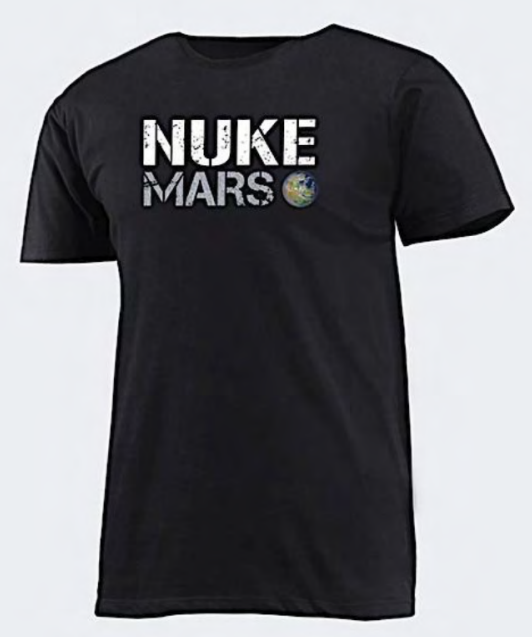

Figure 2: Image courtesy of SpaceX product website 
The fundamental UN treaty foundational to these questions is the Treaty on Principles Governing the Activities of States in the Exploration and Use of Outer Space, including the Moon and Other Celestial Bodies, or simply the "Outer Space Treaty." It was ratified in 1967, largely based on a set of legal principles the United Nations Office of Outer Space Affairs' (UNOOSA) general assembly accepted in 1962 .

The treaty has several major points to it. Some of the key ones include:

- Space is free for all nations to explore, and sovereign claims cannot be made. Space activities must be for the benefit of all nations and humans. (So, nobody owns the moon or other planetary bodies.)

- Nuclear weapons and other weapons of mass destruction are not allowed in Earth orbit, on celestial bodies or in other outer-space locations. (In other words, peace is the only acceptable use of outer-space locations).

- Individual nations (states) are responsible for any damage their space objects cause. Individual nations are also responsible for all governmental and nongovernmental activities conducted by their citizens. These states must also "avoid harmful contamination" due to space activities.

Even NASA, which has been sending probes to Mars for many years, has stated that terraforming Mars is not possible. (NASA is most interested in mining operations on the Red Planet.) Their website states:

Science fiction writers have long featured terraforming, the process of creating an Earth-like or habitable environment on another planet, in their stories. Scientists themselves have proposed terraforming to enable the long-term colonization of Mars. A solution common to both groups is to release carbon dioxide gas trapped in the Martian surface to thicken the atmosphere and act as a blanket to warm the planet.

However, Mars does not retain enough carbon dioxide that could practically be put back into the atmosphere to warm Mars, according to a new NASA-sponsored study. Transforming the inhospitable Martian environment into a place that astronauts could explore without life support, is not possible without technology well beyond today's capabilities.

In the end, Musk's call to "Occupy" and "Nuke" Mars could easily be described as typical "American exceptionalism" and supreme arrogance. His ambitions are mega-terrestrial and he seems to not understand how dangerous his ideas (like launching 10,000 nukes to Mars) really are to those of us still trying to survive on Earth, and to anyone who would be foolish enough to venture to Mars after such a mad scheme had taken place.

It is time for the adults in the room to sit the out-of-control and 
spoiled child down and inform him Elon, you are not going to be the master that he does not own the universe. No, of Mars.

\section{TERRAFORMING MARTIAN ATMOSPHERR?}

O.e of the chalenges of

terroforming Mars is to

increose its otmospheric

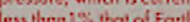
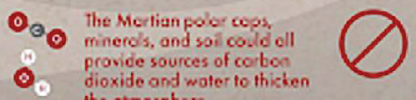

Unfortunately, pecoessing oll

soures available on Mrors

woubd coly increase the pressuce

pravide sources of corbor

the emosphere.

haveut 7 S thet of Earth

0.69
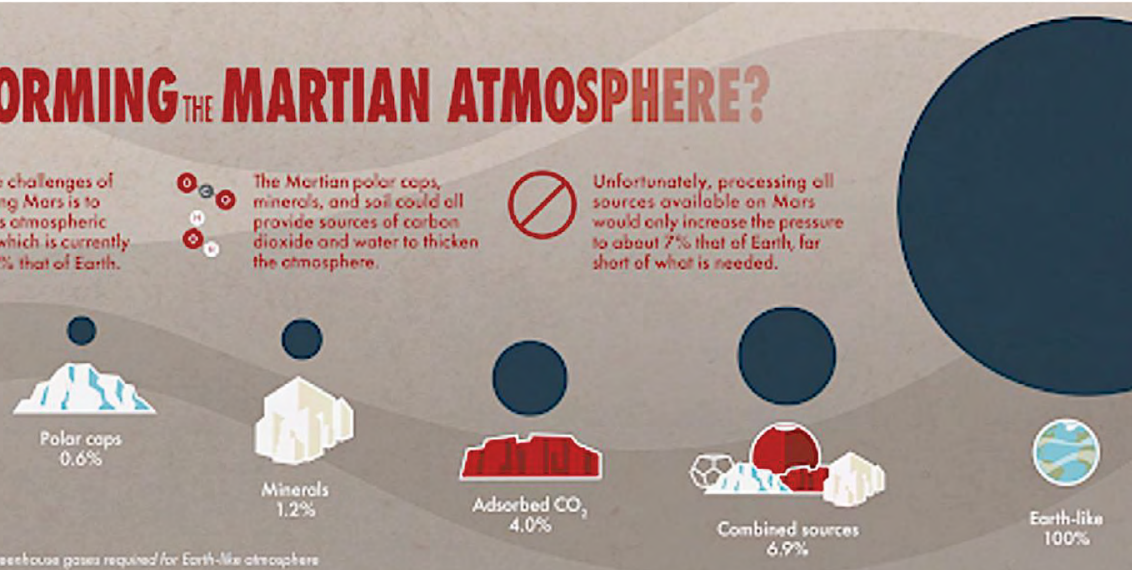

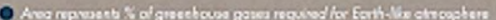

Figure 3. An infographic showing the various sources of carbon dioxide on Mars and their estimated contribution to Martian atmospheric pressure. Credits: NASA Goddard Space Flight Center. 